\title{
TINGKAT KELULUSAN HIDUP BENIH KERAPU MACAN (Ephinephelus fuscoguttatus) PADA FASE PENDEDERAN YANG DIBERI VAKSIN POLYVALEN
}

\section{The Survival Rate of Tiger Grouper (Ephinephelus fuscoguttatus) at Nursery Phase Given Vaccines Polyvalen}

\author{
Oleh: \\ Syamsul Akbar ${ }^{1}$, Marsoedi ${ }^{2}$, Soemarno ${ }^{3}$ dan Endhay Kusnendar ${ }^{4}$ \\ ${ }^{1}$ Mahasiswa S3 Program Doktor Ilmu Perikanan dan Kelautan (FIPK) Unibraw \\ ${ }^{2,3}$ Universitas Brawijaya Malang \\ ${ }^{4}$ Badan LitBang KKP
}

\begin{abstract}
Abstrak
Tujuan penelitian ini adalah untuk mengetahui pengaruh pemberian vaksin polyvalen terhadap tingkat kelulusan hidup ikan kerapu macan (Ephinephelus fuscoguttatus) pada fase pendederan di keramba jaring apung (KJA). Keramba jaring apung yang digunakan sebanyak 18 petak dan setiap petak dipasang jaring berbentuk kurungan berukuran $1 \times 1 \times 1$ meter. Ukuran mata jaring mesh size 0,5 inch dan atau disesuaikan dengan ikan uji yaitu panjang 9,2 $\pm 0,002 \mathrm{~cm}$ dan berat 5,7 $\pm 0,004$ gram. Padat penebaran $75 \mathrm{ekor} / \mathrm{m}^{3} ; 100 \mathrm{ekor} / \mathrm{m}^{3}$ dan $125 \mathrm{ekor} / \mathrm{m}^{3}$, dan pemberian pakan pellet dan pakan ikan rucah. Selama penelitian, ikan uji divaksinasi dengan vaksin polyvalen dosis $10^{6} \mathrm{sel} /$ ikan dan $10^{7} \mathrm{sel} / \mathrm{ikan}$. Sampel darah ikan uji diambil secara acak untuk menganalisis hematologi dan titer antibodi. Selanjutnya memberi vaksin polyvalen dengan ukuran $10^{6} \mathrm{sel} / \mathrm{ikan}$ dan $10^{7}$ sel/ikan untuk masing-masing benih kerapu macan dengan cara penyuntikan (injeksi intraperitoneal). Satu minggu setelah vaksinasi, mengambil sampel darah benih kerapu macan untuk analisis hematologi dan titer antibodinya, kemudian setelah 10 hari lagi, melakukan boster benih kerapu macan, dan setelah 10 hari pembotsteran, mengambil kembali sampel darah untuk analisis hematologi dan titir antibodinya. Pengambilan sample darah ikan uji dilakukan akhir penelitian untuk analisa hematologi dan titer antibodinya Hasil penelitian menunjukkan bahwa pemberian vaksin polyvalen vibrio dengan ukuran $10^{7}$ sel/ikan pada benih kerapu macan (Ephinephelus fuscoguttatus) pada stadia pendederan menghasilkan tingkat kelulusan $82 \%$.
\end{abstract}

Kata kunci: benih, pendederan, polyvalen, vaksin 


\begin{abstract}
The objectives of this study was to determine the effect of giving a polyvalen vaccine against the survival rate of tiger grouper (Ephinephelus fuscoguttatus) at nursery phase in floating net (KJA). Floating net consists of 18 plots and each plot placed net measuring $1 \times 1 \times 1$ meters. Mesh size adjusted to fish size of 0.5 inch test. Tiger grouper seed weight to the size of $5.7 \pm 0.004 \mathrm{~g}$ and $9.2 \pm 0.002 \mathrm{~cm}$ in length. Density of each were 75 ekor/m3; 100 and 125 ekor/m3 ekor/m3, respectively and fed with pellets and trash fish. During study, trials fish were vaccinated with polyvalen vaccine doses $10^{6}$ cell/fish and $10^{7}$ cell/fish. During the study blood samples of fish ware taken by random to analyze hematology and titer antibody. Further provides a vaccine polyvalen to the fish by injection (intraperitoneal injection). One week after vaccination, then blood samples of fish were lakes for hematology analysis and titer antibody, and then after 10 days, fish were bostered, and again after 10 days, blood samples of fish were taken for analysis of hematology and titer antibody. Fish blood sampling tests conducted towards the end of the study for hematology analysis and titer antibody. The result showed that polyvalen vibrio vaccine inoculation with the size of $10^{7}$ cells/fish of tiger grouper (Ephinephelus fuscoguttatus) at nursery phase in floating net (KJA) produces a survival rate of $82 \%$.
\end{abstract}

Keywords : Juvenile, nursery, polyvalen, vaccine

Ikan kerapu macan merupakan salah satu spesies kerapu dengan nilai ekonomi tinggi dan mempunyai prospek yang baik untuk dikembangkan sebagai ikan budidaya karena mempunyai harga jual yang cukup tinggi dan bernilai ekspor. Disamping merupakan komoditas perikanan laut yang bernilai tinggi dan menjadi salah satu komoditas unggulan di Indonesia, ikan ini juga mempunyai pertumbuhan yang cepat. Usaha budidaya ikan kerapu dianggap memiliki prospek yang cerah, karena didukung adanya teknologi pembenihan yang kini telah mulai dikuasai oleh para petani ikan ataupun nelayan (Triana, 2010).

Penyakit karena virus adalah masalah yang sering ditemui dalam budidaya kerapu. Penyakit karena virus biasanya diatasi dengan penggunaan antibiotik dan disinfektan, namun penggunaan antibiotik berdampak negatif yaitu 
timbul mikroba yang resisten, penumpukan residu pada daging ikan dan pencemaran lingkungan. Vaksinasi pada ikan merupakan salah satu cara pencegahan penyakit ikan dengan merangsang kekebalan ikan terhadap penyakit yang tidak menimbulkan dampak negatif pada ikan, lingkungan maupun konsumen (Fasya et al., 2009). Murdjani (1997), menyatakan bahwa akibat rendahnya sintasan pada pembenihan karena adanya infeksi bakteri patogen yang pada kondisi puncak wabah dapat menyebabkan mortalitas sampai $100 \%$.

Virus yang sering menyerang ikan kerapu di Indonesia adalah nervous necrosis virus dan Iridovirus, kedua virus tersebut dapat menimbulkan kematian hingga $80-100 \%$ baik di pembenihan maupun pembesaran. Viral nervous necrosis dan iridovirus dapat menyebabkan penyakit sleepy grouper (Koesharyani et al., 2001).

Vaksinasi merupakan usaha pencegahan sehingga harus dilakukan terhadap ikan yang sehat dan sebelum terjadi serangan penyakit (Kamiso, 1985). Pembentukan antibodi dalam tubuh ikan juga memerlukan waktu sekitar 1-2 minggu yang dipengaruhi oleh status kesehatan ikan yang divaksin dan kualitas lingkungan terutama suhu air (Ellis, 1988). Efektivitas dan efikasi vaksin juga dipengaruhi oleh serotype, jenis vaksin, cara vaksinasi, umur ikan yang divaksin dan kualitas air terutama suhu air (Kamiso, 1985, 1996b; Kamiso et al., 1993).

Hasil uji laboratorium ini menunjukkan bahwa vaksin polyvalen dapat meningkatkan sintasan hingga $100 \%$ dari serangan Vibrio. Hasil yang serupa pernah dilaporkan oleh Bricknell et al. (2000) pada Atlantic halibut yang divaksin dengan vaksin Vibrio anguillarum. Atlantic halibut yang tidak divaksin mempunyai sintasan $65-80 \%$, sedangkan sintasan ikan yang divaksin mencapai $100 \%$. Sintasan $100 \%$ ini dicapai oleh kerapu tikus yang divaksin dengan cara suntikan, rendaman maupun oral (Kamiso et al., 2005). Vaksinasi pada Epinephalus awoara untuk menanggulangi vibriosis menghasilkan sintasan berkisar antara 10-100\% tergantung cara vaksinasi yang digunakan.

Tujuan penelitian ini adalah untuk menentukan pengaruh pemberian vaksin polyvalen terhadap tingkat kelulusan hidup benih kerapu macan (Ephinephelus fuscoguttatus) pada stadia 
pendederan dalam keramba jaring apung (KJA).

\section{Materi dan Metode}

Kerapu macan (Ephinephelus fuscoguttatus) sebagai bahan penelitian ukurannya seragam, dengan berat 5,7 $\pm 0,004$ gram dan pajang 9,2 $\pm 0,002 \mathrm{~cm}$, yang berasal dari hatchery Balai Budidaya Laut Batam. Pendederan kerapu macan menggunakan keramba jaring apung ukuran $1 \times 1 \times 1$ meter, dengan padat penebaran $75 \mathrm{ekor} / \mathrm{m}^{3} ; 100$ ekor $/ \mathrm{m}^{3}$ dan $125 \mathrm{ekor} / \mathrm{m}^{3}$, dan pemberian pakan pellet kandungan protein minimum $50 \%$ dan pakan ikan rucah (ikan tajan).

Percobaan dirancang dalam rancangan acak kelompok (RAK) dengan dua perlakuan yaitu A. pemberian vaksin polyvalen ukuran $10^{6}$ sel/ikan dan B. vaksin polyvalen ukuran $10^{7}$ sel/ikan. Masing-masing perlakuan terdiri dari 3 ulangan.

Pemberian vaksinasi pada benih kerapu macan dengan cara mengambil sampel darah kerapu macan secara acak, untuk menganalisis hematologi dan titer antibodinya. Selanjutnya memberi vaksin polyvalen dengan ukuran $10^{6} \mathrm{sel} / \mathrm{ikan}$ dan $10^{7} \mathrm{sel} / \mathrm{ikan}$ untuk masing-masing benih kerapu macan dengan cara penyuntikan (injeksi intraperitoneal dan injeksi intramuskular). Satu minggu setelah vaksinasi, selanjutnya mengambil sampel darah benih kerapu macan untuk analisis hematologi dan titer antibodinya, kemudian setelah 10 hari lagi, melakukan boster benih kerapu macan, dan setelah 10 hari pembotsteran, mengambil kembali sampel darah untuk analisis hematologi dan titir antibodinya. Pengambilan sample darah ikan uji akan dilakukan menjelang akhir penelitian kembali untuk analisa hematologi dan titer antibodinya.

Parameter pengamatan meliputi pertambahan berat dan panjang, mortalitas, rasio konversi pakan, protein atau energi rasio, titer antibodi, produksi $\left(\mathrm{kg} / \mathrm{m}^{3}\right)$ dan \%sintasan ikan kerapu macan, yang diukur pada setiap setiap 2 minggu sekali. Sementara untuk data penunjang kualitas air pengamatan dilakukan 1 minggu sekali, yang meliputi DO, pH, salinitas, suhu, $\mathrm{NO}_{3}, \mathrm{NO}_{2}$, amoniak dan kecerahan.

\section{Hasil dan Pembahasan}

Penanganan dan pencegahan penyakit kerapu macan selama pendederan 90 hari dengan cara melakukan vaksinasi. Sebelum melakukan vaksinasi, tahapan awal adalah mempersiapkan vaksin polyvalen vibrio dari laboratorium, selanjutnya melakukan uji coba vaksin untuk skala laboratorium. 
Dalam uji laboratorium ini menggunakan ikan kerapu dengan berat 5,7 $\pm 0,004$ gram, dan panjang awal 9,2 $\pm 0,002 \mathrm{~cm}$. Tahapan selanjutnya adalah mengkondisikan kerapu macan dalam keramba jaring apung dengan padat penebaran 75 ekor $/ \mathrm{m}^{3} ; 100$ ekor $/ \mathrm{m}^{3}$ dan 125 ekor/m $\mathrm{m}^{3}$. 7-10 hari setelah vaksinasi, tahapan kegiatan adalah melakukan booster kerapu macan, dengan tujuan untuk meningkatkan produksi titer antibodinya. Cara melakukan vaksinasi dalam uji skala laboratorium ini adalah dengan penyuntikan (injeksi intraperitoneal dan injeksi intramuskular).

Empat belas hari setelah booster, tahapan selanjutnya adalah mengambil sampel darah ikan uji untuk pengamatan titer antibodi. Data hasil pengamatan uji darah ikan sebelum dan setelah vaksin serta setelah booster, secara lengkap tersaji pada Tabel 1. Waktu pelaksanaan booster adalah 7 hari setelah vaksinasi, 7 hari setelah booster, tahapan selanjutnya adalah memindahkan benih kerapu macan dalam karamba jaring apung berukuran jaring $1 \times 1 \times 1 \times 1 \mathrm{~m}^{3}$ dengan kepadatan 75 ekor $/ \mathrm{m}^{3}, 100$ ekor $/ \mathrm{m}^{3}$ dan $125 \mathrm{ekor} / \mathrm{m}^{3}$, selanjutnya memelihara benih kerapu macan selama 90 hari yaitu mulai bulan Mei sampai dengan Agustus 2009.

Tabel 1. Hasil analisa darah ikan kerapu macan

\begin{tabular}{|l|c|c|c|}
\hline \multirow{2}{*}{\multicolumn{1}{|c|}{ Parameter }} & \multicolumn{3}{|c|}{ Hasil Analisa Darah Ikan } \\
\cline { 2 - 4 } & $\begin{array}{c}\text { Sebelum } \\
\text { vaksin }\end{array}$ & $\begin{array}{c}\text { Setelah } \\
\text { vaksin }\end{array}$ & $\begin{array}{c}\text { Setelah } \\
\text { Booster }\end{array}$ \\
\hline Haemoglobin $(\mathrm{g} / \mathrm{dl})$ & 5,8 & 6,6 & 6,9 \\
Leukosit $(\mathrm{j} / \mu$ liter $)$ & 486,500 & 502,250 & 568,189 \\
Hematokrit $(/ \mu$ liter $)$ & 27,6 & 32,4 & 33,9 \\
Trombosit $(/ \mu$ liter $)$ & 232,050 & 288,000 & 312,000 \\
Eritrosit $(j u t a / \mu$ liter $)$ & 1,54 & 1,87 & 2,02 \\
\hline
\end{tabular}

Sumber: data pengamatan penelitian keramba jaring apung di Batam (2010) 
Hasil pengamatan selama 90 hari dan pemberian vaksin polyvalen vibrio dengan ukuran $10^{7} \mathrm{sel} / \mathrm{ikan}$ menunjukkan bahwa sintasan benih kerapu macan tertinggi adalah $82 \%$, pada kondisi padat penebaran $75 \mathrm{ekor} / \mathrm{m}^{3}$, sementara pada kondisi padat penebaran 100 ekor $/ \mathrm{m}^{3}$ dan 125 ekor/ $\mathrm{m}^{3}$, nilai sintasan masingmasing adalah $79 \%$ dan $68 \%$.

Uji efektivitas dan daya imunogenisitas vaksin inaktif terhdap iridovirus di Laboratorium Patologi, Balai Besar Riset Perikanan Budidaya Laut, GondolBali. Juvenil kerapu pasir, Epinephelus corallicola melalui injeksi secara intraperitoneal dengan virus inaktif dengan dua konsentrasi, yaitu $0,1 \mathrm{~mL}$ vaksin stok/ikan dan $0,1 \mathrm{~mL}$ vaksin yang sudah dincerkan $\left(10^{-4}\right)$; selanjutnya menginjeksi ikan kontrol dengan 0,1 mL PBS/ekor, setelah melakukan uji tantang dapat menghasilkan sintasan sebesar 93,33-100\%, sementara sintasan ikan kontrol 55,56\% (Roza et al., 2007).

Mahardika et al. (2002) menyatakan hasil penelitiannya bahwa jumlah (presentase) kematian kelompok ikan kontrol vaksin yang ditantang dengan virus viral nervous necrosis pada konsentrasi $10^{-5}$ yaitu 35 ekor (70\%) dan konsentrasi $10^{-4}$ yaitu 38 ekor $(76 \%)$ lebih tinggi dibanding dengan kelompok ikan vaksin yang ditantang dengan virus viral nervous necrosis pada konsentrasi $10^{-5}$ yaitu 3 ekor (6\%) dan konsentrasi $10^{-4}$ yaitu 5 ekor (10\%). Hasil tersebut menunjukkan bahwa pemberian vaksin (inaktif vaksin dengan $0,5 \%$ formalin secara intramuskular) pada yuwana kerapu bebek dapat mencegah atau mengurangi kematian ikan akibat serangan viral nervous necrosis.

Roza et al. (2004), menyatakan bahwa hasil diuji tantang dengan viral nervous necrosis memperlihatkan perlakuan $15 \mathrm{~mL} / \mathrm{L}$ memberikan hasil dengan sintasan sebesar $86,67 \%$ setelah 25 hari pasca vaksinasi. Hasil pada percobaan tahap II adalah; pada perlakuan perendaman selama 3 jam memberikan sintasan setelah uji tantang sebesar $86,67 \%$ setelah 20 hari pasca vaksinasi. Vaksinasi dengan viral nervous necrosis pada dosis $15 \mathrm{~mL} / \mathrm{L}$ dengan lama perendaman 3 jam dapat meningkatkan imunitas yuwana ikan kerapu bebek terhadap infeksi viral nervous necrosis.

Roza et al. (2010) menyatakan hasil penelitiannya bahwa titer 
antibodi kelompok ikan yang divaksin lebih tinggi (1/64) dibanding kontrol (1/4). Begitu juga dengan nilai sintasan dimana sintasan rata-rata pada kelompok ikan yang divaksin lebih tinggi (80\%) dibanding kontrol (56\%). Sintasan ikan hasil uji tantang adalah $87 \%$ dan kontrol $66 \%$. Hasil ini membuktikan bahwa vaksin yang diberikan efektif meningkat kekebalan spesifik Yuwana kerapu macan.

\section{KESIMPULAN DAN SARAN} Kesimpulan

Pemberian vaksin polyvalen vibrio dengan ukuran $10^{7} \mathrm{sel} / \mathrm{ikan}$ pada benih kerapu macan (Ephinephelus fuscoguttatus) pada stadia pendederan menghasilkan tingkat kelulusan $82 \%$.

\section{Saran}

Berdasarkan hasil penelitian tersebut diatas, perlu dilakukan uji vaksin polyvalen pada spesies ikan kerapu lainnya, untuk mencegah penyakit ikan yang berasal dari virus.

\section{DAFTAR PUSTAKA}

Bricknell, I.R., T.J. Bowden, D.W. Verner-Jeffreys, D.W. Bruno, R.J. Shields and A.E. Ellis. 2000. Susceptibility of juvenile and sub-adult
Atlantic halibut (Hippoglossus hippoglossus L.) to infection by Vibrio anguillarum and efficacy of protection induced by vaccination. Fish Shellfish Immunol. 10(4):p. 319327Ellis, A.E., 1988. Fish Vaccination. Academic Press LTD. London

Fasya, M.A., M. Sarida dan J. Dewi, 2009. Studi Waktu vaksinasi Tahap kedua yang Berbeda Terhadap Mortalitas Ikan Kerapu Macan (Epinephelus fuscoguttatus). Program Studi Budidaya Perairan Universitas Lampung

Kamiso, H.N. 1985. Differences in Pathogenicity and Pathology of Vibrio anguillarum and Vibrio ordalii in Chum Salmon (Oncorhynchus keta) and English Sole (Parophrys vetulus) under Laboratory Conditions. Ph.D. Thesis submitted to Oregon State University, p. 116

Kamiso, H.N. 1993. Pembuatan vaksin monovalen dan polivalen untuk mengatasi serangan Aeromonas 
hydrophyla pada ikan lele (Clarias sp.). Pros. Seminar Hasil Penelitian PT. 5-9 Februari 1993. Cisarua Bogor. DP4M. Dikti. Depdikbud.

Kamiso, H.N. 1996b. Vaksinasi indukuntuk meningkatkan kekebalan bibit lele dumbo (Clarias gariephunus) terhadap serangan Aeromonas hydrophyla.Bul. Ilmu Perikanan (7): Hal. 1018

Koesharyani, I., D. Roza, K. Mahardika, F. Johnny,Zafran and K. Yuasa. 2001. Marine Fish and Crustaceans Diseases in Indonesia In Manual for Fish Diseases Diagnosis II $(E d$. by $\mathrm{K}$. Sugama, K. Hatai and $T$. Nakai). 49 p. Gondol Research Station for Coastal Fisheries, CRIFI and Japan International Cooperation Agency

Mahardika, K., I. Koesharyani dan Tridjoko, 2002. Upaya Pencegahan Penyakit Viral Nervous Necrosis Pada Yuwana Kerapu Bebek (Cromileptes altivelis) Melalui Vaksinasi. Balai
Besar Riset Perikanan Budidaya Laut, Gondol. Jurnal Penelitian Perikanan Indonesia Vol. 8 No. 5. Hal. 1

Murjani, M., 1997. Pembenihan Ikan Kerapu Tikus (Cromileptes altivelis) dalam Bak Terkendali di Loka BBAP Situbondo. Ditjen Perikanan, Deptan

Roza, D., F. Johnny dan Tridjoko, 2004.

Peningkatan

Imunitas Yuwana Ikan Kerapu Bebek, Cromileptes altivelis Terhadap Infeksi Viral Nervous Necrosis (VNN) dengan Cara Vaksinasi Melalui Perendaman. Jurnal Penelitian Perikanan Indonesia, 10 (1) :61-70

Roza, D., F. Johnny dan Zafran. 2007. Aplikasi dan Efektivitas Vaksin Anti Parasit pada Pembenihan Ikan Kerapu Pasir (Ephinephelus corallicola) di Hatchery. Laboratorium Patologi Balai Besar Riset Perikanan Budidaya Laut Gondol Bali. Hal. 1 
Roza, D., F. Johnny dan Zafran. 2010. Pengembangan Vaksin Bakteri untuk Meningkatkan Imunitas Ikan Kerapu Macan (Epinephelus fuscoguttatus) Terhadap Penyakit Infeksi. Balai Besar Riset Perikanan Budidaya Laut. Prosiding Forum Inovasi Teknologi Akuakultur. Hal. 939-944

Triana, H., 2010. Analisis Fragmen DNA Ikan Kerapu Macan (Epinephelus fuscoguttatus) yang Tahan dan Rentan terhadap Bakteri Vibrio alginolyticus Analysis of DNA Fragment Obtained from Groupers (Epinephelus fuscoguttatus) Challenged by Vibrio alginolyticus. FPIK UMI Makassar. Jurnal ILMU DASAR, Vol. 11 No.1, Januari $2010: 8-16$ 
Jurnal Teknologi Pangan Vol.3 No.1

Juni 2012 